Bangladesh J. Pl. Breed. Genet., 27(1): 25-36, 2014

\title{
VARIABILITY AND CORRELATION STUDY OF SOME ADVANCED LINES OF Brassica rapa
}

\author{
T. Halder, M. S. R. Bhuiyan and M. S. Islam \\ Department of Genetics and Plant Breeding, \\ Sher-e-Bangla Agricultural University, Dhaka-1207
}

\begin{abstract}
Variability, heritability, genetic advance and correlation were assessed in eleven advanced lines of Brassica rapa obtained through inter-varietal crosses along with three popular check varieties at the experimental field of Sher-e-Bangla Agricultural University. Significant variations were found in yield per hectare and all the yield components that were taken under the study. Highest yield per hectare $(2111.33 \mathrm{~kg}$ ) was found in SAUSR 14 (TORI-7×BARI Sarisha-9). The advanced line SAUSR 08 (BARI Sarisha-6xTORI-7) matured early (83.67 days) and produced moderate yield $(1662.00 \mathrm{~kg})$. It could be assumed from the mean performance that SAUSR 14 and SAUSR 08 showed better performance over the popular check varieties in respect of yield and maturity. Highest GCV (20.06\%) and PCV (31.71\%) were observed in number of siliquae per plant. Genotypic variance was lower than phenotypic variance for all characters except yield per hectare. High heritability in broad sense $(91.14 \%$ and $79.25 \%$ ) was observed for days to $50 \%$ flowering and days to $80 \%$ flowering. Highest genetic advance $(36.56 \%)$ was found for number of siliquae per plant. Low heritability (29.27\%) with high genetic advance $(23.14 \%)$ was observed for yield per hectare. Highly positive significant phenotypic correlation with yield per hectare was seen in days to $80 \%$ maturity and number of secondary branches per plant. Days to $50 \%$ flowering and siliquae length showed negative highly significant phenotypic correlation with the yield per hectare.
\end{abstract}

Keywords: Variability; heritability; genetic advance; phenotypic correlation intervarietal crosses; advanced lines

\section{INTRODUCTION}

Brassica is a species under family Brassicaceae contributes to approximately $12 \%$ of the world wide edible oil supply (USDA, 2014). The cultivated Brassica species are Brassica rapa, Brassica nigra and Brassica oleracea (Nagaharu, 1935). Brassica can be grouped into rapeseed, mustard and cole (Yarnell et al., 1956). Among the oilseed crops, mustard and rape seed is in second position after soybean (FAO, 2005). About $13.2 \%$ of edible oil comes from the crop (Downey and Robbelen, 1989). It is the top ranking oil seed crop in Bangladesh that covers about $68 \%$ of the total acreage land (BBS, 2011).

Brassica rapa is the main oil yielding species of Brassica in Bangladesh (FAO, 2013). It occupies 25223.8 ha cultivated area which produces 0.246 million ton seeds and the average yield is 0.997 million $\mathrm{t} \mathrm{ha}^{-1}$ during 2010-2011 (BBS, 2011). However, the amount of the seed production is very low to meet the total oil requirement. To fill up the demand, Bangladesh imports 0.08997 million tons edible oil that costs 371.85 million taka (BBS, 2011). 
There are almost twenty one varieties of $B$. rapa including some high yielding varieties. In spite of high yielding varieties the increase of area of production seems impossible in the existing cultivable land. The yield of $B$. rapa is very poor in

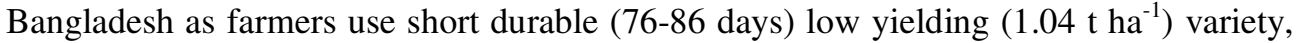
TORI-7 that is generally well fitted to the Aman-rapeseed-Boro cropping pattern especially where there is a problem of drought at one or more stages of crop growth. On the other hand the results of different experiment showed that the days to maturity of the high yielding varieties like BARI Sarisha 15 and BARI Sarisha 17 varies 84-92 days and 86-94 days to maturity that are considered as late varieties. Hence, it is the important task for breeder to develop short duration ( 80 days) and better yielding rapeseed varieties that would be well fitted in three cropped cropping pattern.

Variability, heritability and genetic advance is very important strategies for breeding program to develop promising varieties (Iqbal et al., 2014). Certain morphological parameters are considered as important tools for estimation of variability (Ali et al., 2013). As yield is a polygenic character, it is influenced by the environment (Gaines et al., 1996; Novoselovic et al., 2004). The relative influence of genes and environment can be determined by heritability that indicates the extent of successful transmission of characters to the next generation. The relationship between heritability and response to selection can be determined directly by genetic progress where the expected response to selection is termed as genetic advance (Iqbal et al., 2014). Heritability along with genetic advance is very important in breeding program as high heritability with high genetic advance indicates best selection for the character due to presence of additive genes for controlling it.

Yield has the foremost importance in plant breeding. To ensure the replacement of former variety by the newly developed variety, a slight superiority of new one over the commercial variety is enough. Correlation co-efficient analysis is assessed by scientists to select better plant that leads to a directional model for yield response by the important plant characters (Khan et al., 2008).

In this context, the present experiment was conducted by utilizing fourteen Brassica rapa genotypes (eleven advanced breeding lines including three popular check varieties) to study variability, heritability, genetic advance and correlation to select promising genotypes.

\section{MATERIALS AND METHOD}

The experiment was conducted at the experimental farm of the Department of the Genetics and Plant Breeding, Sher-e-Bangla Agricultural University during November 2013 to February 2014. Fourteen genotypes including eleven advanced lines that were obtained from various inter-varietal crosses of six and more than six generations and three check varieties (BARI Sarisha-14, BARI Sarisha-15 and TORI-7) were used as experimental materials. The list of the advanced lines is presented in table 1. Randomized Complete Block Design (RCBD) was used with 3 replications of the material. Each plot consisted of single row of $3 \mathrm{~m}$ length with $30 \mathrm{~cm}$ spacing between the rows and $10 \mathrm{~cm}$ between the plants. Cowdung was used $13 \mathrm{t} \mathrm{ha}^{-1}$ while Urea: Triple Super Phosphate (TSP): Muriate of Potash (MP): Gypsum: Zinc Sulphate: Boric Acid was applied as $251: 184: 85: 152: 3: 13 \mathrm{~kg} \mathrm{ha}^{-1}$. The cowdung was applied before the chemical fertilizer applications. The TSP, MP, Gypsum, Zinc Sulphate, Boric Acid and $50 \%$ Urea were used as basal dose and the rest $50 \%$ Urea was used as top dressing at the flower initiation stage. First weeding and thinning was done at 15 DAS (Days after Sowing) and top dressing, second weeding and thinning was done at 25 DAS. Ten plants 
of each genotypes of each replication were taken for data collection. Data was recorded on days to first flowering, days to $50 \%$ flowering, days to $80 \%$ flowering, days to maturity, plant height $(\mathrm{cm})$,number of primary branches per plant, number of secondary branches per plant, number of siliquae per plant, length of silique $(\mathrm{cm})$, number of seeds per siliquae, yield per hectare $(\mathrm{kg})$ and thousand seed weight $(\mathrm{g})$. Mean data of the yield contributing characters were used for statistical analysis. Least Significant Difference (LSD) test was done according to Gomez and Gomez, 1984. Genotypic and phenotypic variance was estimated according to the formula of Johnson et al., 1995. Heritability and genetic advance was measured by using the formula given by Singh and Chaudhary, 1985 and Allard, 1960. All statistical analysis was accomplished by MSTAT and GENSTAT, computer based software.

Table 1. Name of the advanced lines with their abbreviated forms

\begin{tabular}{|c|c|}
\hline Name of the lines & Crosses \\
\hline 1. SAUSR 04 & $F_{6} \times$ BARI Shrisha- $9 \quad S_{1}$ \\
\hline 2. SAUSR 05 & $\mathrm{~F}_{6} \times$ BARI Sarisha- $9 \quad \mathrm{~S}_{2}$ \\
\hline 3. SAUSR 06 & $\mathrm{~F}_{6} \times$ BARI Sarisha- $9 \quad \mathrm{~S}_{3}$ \\
\hline 4. SAUSR 07 & BARI Sarisha-6x Tori-7 $S_{1}$ \\
\hline 5. SAUSR 08 & BARI Sarisha- $6 \times$ Tori- $7 \mathrm{~S}_{2}$ \\
\hline 6. SAUSR 09 & BARI Sarisha-9 $\times$ BARI Sarisha- $6 S_{1}$ \\
\hline 7. SAUSR 10 & BARI Sarisha-9 $\times$ BARI Sarisha- $6 \mathrm{~S}_{2}$ \\
\hline 8. SAUSR 11 & BARI Sarisha-9 9 BARI Sarisha- $6 \mathrm{~S}_{3}$ \\
\hline 9. SAUSR 12 & $\mathrm{SS}_{75} \times$ Tori- 7 \\
\hline 10. SAUSR 13 & BARI Sarisha- $9 \times \mathrm{F}_{6}$ \\
\hline 11. SAUSR 14 & Tori-7× BARI Sarisha-9 \\
\hline
\end{tabular}
$\mathrm{S}_{1}=$ Line $1, \mathrm{~S}_{2}=$ Line 2 and $\mathrm{S}_{3}=$ Line3

\section{RESULTS AND DISCUSSION}

\section{Variability}

The presence of variability is the prerequisite for any breeding program. The Analysis of Variance (ANOVA) of the data of yield components and yield of $B$. rapa is presented in table 2 represented that there were significant variations among the characters at $5 \%$ and $1 \%$ level of probability. Days to $50 \%$ flowering, days to $80 \%$ flowering, number of siliqua per plant, number of seeds per siliquae, length of silique showed significant variances at $1 \%$ level of probability and the rests were significant at $5 \%$ level of probability. This wide range of variability indicated that these traits were very much important for developing promising varieties especially which will be high yielding. The Co-efficient of Variation (CV) was ranged in $4.38 \%$ to $41.84 \%$. It was revealed that the lowest $\mathrm{CV}(\leq 20 \%)$ values showed best genetic potential and influence. The highest CV (41.84\%) for was found in number of secondary branches per plant indicated that there were more influence of environmental fluctuation for the phenotypic expression of the trait. 
Table 2. Analysis of variance of the data of 12 characters of 14 genotypes of Brassica rapa

\begin{tabular}{|c|c|c|c|c|c|c|c|c|c|c|c|c|c|}
\hline \multirow{2}{*}{ Source of Variance } & \multirow{2}{*}{$\mathbf{D F}$} & \multicolumn{12}{|c|}{ Mean Sum of Square of the Characters } \\
\hline & & DFF & DFiF & DEF & PH (cm) & NPBP & NSBP & DM & NSP & NSS & SL (cm) & TSW (g) & YH (kg) \\
\hline Replication & 2 & 0.67 & 20.67 & 21.24 & 35.54 & 0.17 & 0.738 & 74.59 & 433.79 & 7.39 & 0.17 & 0.001 & 292491.52 \\
\hline Genotype & 13 & $25.63^{*}$ & $54.76^{* *}$ & $68.13^{* *}$ & $183.16^{*}$ & $3.06^{*}$ & $8.690^{*}$ & $72.86^{*}$ & $3907.91^{* *}$ & $11.66^{* *}$ & $0.92^{* *}$ & $0.50^{*}$ & $257808.33^{*}$ \\
\hline Error & 26 & 10.05 & 1.72 & 5.47 & 77.92 & 1.09 & 3.251 & 30.16 & 1301.32 & 3.54 & 0.36 & 0.19 & 115013.85 \\
\hline $\mathrm{CV} \%$ & & 12.71 & 4.38 & 7.11 & 10.43 & 18.82 & 41.84 & 6.35 & 24.55 & 10.72 & 11.23 & 12.66 & 21.42 \\
\hline
\end{tabular}

*Denote significant at $5 \%$ level of probability, $* *$ Denote significant at $1 \%$ level of probability

$\mathrm{DFF}=$ Days to $1^{\text {st }}$ flowering, DFiF=Days to $50 \%$ flowering, DEF=Days to $80 \%$ flowering, $\mathrm{PH}=\mathrm{Plant}$ Height, NPBP=Number of Primary Branches per Plant, NSBP= Number of Secondary Branches per Plant, DM=Days to Maturity, NSP=Number of Siliquae per Plant, NSS=Number of Seeds per silique, SL=Siliquae Length, TSW=Thousand Seed Weight, YH=Yield per Hectare 
Mean performance with categorization of the characters of fourteen genotypes are presented on table 3. In case of days to first flowering, SAUSR 09 was earliest flowering (21.33 days) line and BARI Sarisha 15 is the latest (33 days) variety showing high significant difference between them. BARI Sarisha-15, BARI Sarisha-14 and SAUSR 09 showed significant difference to each other in days to $50 \%$ flowering. The range of earliest and latest genotype in the case was 26 days to 43.67 days. High significant differences were found in BARI Sarisha-14, TORI-7, BARI Sarisha-15, SAUSR 08 and SAUSR 09 in case of days to $80 \%$ flowering where range was 29.33 days to 48 days. BARI Sarisha-15 and SAUSR 06 showed highly significant difference among the genotypes in plant height ranging from $63.45 \mathrm{~cm}$ to $93 \mathrm{~cm}$.

There was no significant difference among SAUSR 06, SAUSR 12 and SAUSR 13 but significantly different with the BARI Sarisha-15 in number of primary branches per plant giving a range of 4.33 to 8.33 . More number of primary branches per plant might indicate more yield due to more number of siliquae per plant. It was also found in the study that BARI Sarisha-15 with highest number of primary branches per plant had better number of siliquae per plant (129) and produced more yield (2012.67 kg/ha). The range for number of secondary branches per plant was 1.67 to 8.67. SAUSR 09, SAUSR 05, SAUSR 08 and SAUSR 07 were significantly different from each other as well as among the other genotypes in number of secondary branches per plant.

In case of days to maturity, SAUSR 04 and SAUSR 13, the earliest matured line showed significant difference from all the other genotypes while SAUSR 08, SAUSR 09 AND SAUSR 10 showed very little and non-significant difference with SAUSR 13. The range of maturity was 80.67 days to 95.67 days. It was found that days to maturity was directly proportional to the increase of yield per hectare. SAUSR 04 was the latest matured line produced higher yield while SAUSR 14 with higher days to maturity. On the other hand, the popular check variety for short duration, TORI-7 produced moderate yield while the earliest genotype SAUSR 13 produce lower yield than the check. Here, we can consider the line for further improvement for higher yield. Among the lines, SAUSR 08 was earlier matured lines with moderately high yield that was more than the check variety TORI-7.

SAUSR 04, SAUSR 11 and BARI Sarisha-15 showed significant difference to all other genotypes in number of siliquae per plant that had a range of 80.67 to 218 . SAUSR 08 and SAUSR 14 was observed with more number of siliquae per plant than the check varieties indicating higher yield.

Non-significant difference was found among BARI Sarisha-14, BARI Sarisha-15 and SAUSR 08 but significant difference to other genotypes in case of seeds per sililqua with a range of 15.43 to 21.69. SAUSR 06 and BARI Sarisha-14 showed very significant difference to each other in case of siliquae length with a range of $4.03 \mathrm{~cm}$ to $6.14 \mathrm{~cm}$. The range of thousand seed weight was $2.93 \mathrm{~g}$ to $4.3 \mathrm{~g}$. TORI-7 and SAUSR 07 showed non-significant differences but very significant difference to SAUSR 08 for thousand seed weight.

Yield per hectare area was found in non-significant difference in SAUSR 11 and SAUSR 12 but very significant difference with SAUSR 14 which showed highest yield. It was observed that SAUSR 14 had less plant height, number of primary branches per plant and number of seeds per siliquae but more number of secondary branches per plant, number of siliquae per plant, siliquae length and thousand seed weight than the high yielding check variety BARI Sarisha 15 . But it showed non-significant difference in days to maturity. So the line might be a more promising high yielding variety in aspect of yield than the present varieties. 
The genetic parameters for yield and yield contributing characters of the concerned genotypes are presented in table 4. It was found from the table that that phenotypic variance was always higher than the genotypic variance that indicated the presence of influence of environment over the characters. Lowest difference of genotypic and phenotypic variance was seen in thousand seed weight while the highest environmental variance was in yield per hectare. Higher PCV than GCV indicated that the variation was due to not only for genotype but also for environment. High PCV and GCV was found in number of secondary branches per plant, number of siliquae per plant and yield per hectare and similar results was found by Khan et al. (2013a), Roy et al. (2011) and Naznin (2013). Very low difference of PCV and GCV and lowest ECV was seen in days to 50\% flowering indicated higher influence of genotype for the trait and it was also found by Jahan (2008).

\section{Heritability and genetic advance:}

Heritability and genetic advance is very much important for selecting best lines in breeding programs. Heritability along with genetic advance is more useful for estimating the selection effect than the heritability alone. In the present study, heritability in broad sense and expected response to the selection and its percentage in mean were determined for yield and different yield components presented in table 3 . Heritability values were categorized into high $(>60 \%)$, moderate $(30-60 \%)$ and low $(\leq 30 \%)$ while genetic advance in percent of mean was considered as high ( $\geq 20 \%)$, moderate (10-20\%) and low $(\leq 10 \%)$.

Moderate heritability with low genetic advance in percent of mean was found in days to first flowering. High heritability in broad sense with fairly high genetic advance in percent of mean was found in days to $50 \%$ flowering and days to $80 \%$ flowering indicated presence of additive genes. High genetic advance due to the result of additive gene action was also reported by Khan et al. (2013b), Kahrizi and Allahvarand (2012).

Moderate heritability with low genetic advance was found in plant height and silique length. The phenotypic variance is much more than the genotypic variance indicated that the environmental influence was much more in the expression for plant height while there were very little difference in siliquae length. High heritability (92.48\%) with moderate genetic advance (18.87\%) was found by Saifullah (2012) for the trait where Naznin (2013) found high heritability (71.01\%) with low genetic advance $(9.49 \%)$ for plant height.

Number of primary branches per plant was found with moderate heritability and moderate genetic advance in percentage of mean and very low difference in genotypic and phenotypic variance indicated moderate influence of environment upon the character. The results were contradictory in line with the findings of Junaid et al. (2014) who observed high heritability (72\%) with moderate genetic advance in percent of mean $(18.32 \%)$.

It was noted that number of secondary branches per plant and number of siliquae per plant showed moderate heritability with low genetic advance and high genetic advance in percent of mean indicated moderate effect of environment and presence of non-additive gene in the expression of character but much scope to improve. Akter (2010) reported high heritability $(89.65 \%)$ with low genetic advance in percent of mean (3.50\%) for number of secondary branches per plant and Khan et al. (2013b) supported the result with moderate heritability $(35.65 \%)$ with high genetic advance in percent of mean $(48.78 \%)$ for number of siliquae per plant. 
Table 3. Mean performance with categorization and genetic parameters of of twelve characters of 14 genotypes of Brassica rapa

\begin{tabular}{|c|c|c|c|c|c|c|c|c|c|c|c|c|}
\hline Lines and parameters & DFF & DFiF & DEF & $\mathrm{PH}(\mathrm{cm})$ & NPBP & NSBP & DM & NSP & NSS & SL (cm) & $\mathrm{TSW}(\mathrm{g})$ & YH (kg) \\
\hline SAUSR 04 & $24.33 \mathrm{bc}$ & $30.33 \mathrm{bcd}$ & $32.33 b c$ & $90.33 \mathrm{ab}$ & $5.00 \mathrm{bc}$ & $4.33 \mathrm{bcd}$ & $95.67 \mathrm{a}$ & $218.00 \mathrm{a}$ & $17.85 \mathrm{~b}$ & $5.73 \mathrm{ab}$ & 3.58abcd & $1830.00 \mathrm{abc}$ \\
\hline SAUSR 05 & $22.33 b c$ & $28.00 \mathrm{cde}$ & $31.33 b c$ & $84.00 \mathrm{ab}$ & $5.33 b c$ & $5.67 \mathrm{~b}$ & 91.33abc & $182.33 \mathrm{ab}$ & $16.23 \mathrm{~b}$ & $5.17 \mathrm{abc}$ & $3.16 \mathrm{~cd}$ & 1643.33abcd \\
\hline SAUSR 06 & $24.67 \mathrm{bc}$ & $29.00 \mathrm{cde}$ & $31.33 b c$ & $63.45 \mathrm{c}$ & $4.67 \mathrm{c}$ & $4.00 \mathrm{bcd}$ & $89.00 \mathrm{abc}$ & $125.33 b c$ & $16.65 \mathrm{~b}$ & $6.14 \mathrm{a}$ & $3.33 \mathrm{~cd}$ & $1606.33 \mathrm{abcd}$ \\
\hline SAUSR 07 & $24.67 b c$ & $28.00 \mathrm{cde}$ & $32.33 \mathrm{bc}$ & $79.67 \mathrm{ab}$ & $5.00 \mathrm{bc}$ & $1.67 \mathrm{~d}$ & $86.67 \mathrm{abc}$ & $113.33 b c$ & $17.20 \mathrm{~b}$ & $5.53 \mathrm{abc}$ & $2.95 \mathrm{~d}$ & $1428.67 \mathrm{abcd}$ \\
\hline SAUSR 08 & $24.33 b c$ & $28.33 \mathrm{cde}$ & $29.33 c$ & $90.67 \mathrm{ab}$ & $6.00 \mathrm{bc}$ & $5.33 b c$ & $83.67 b c$ & $175.33 \mathrm{ab}$ & $18.97 \mathrm{ab}$ & $5.83 \mathrm{ab}$ & $4.37 \mathrm{a}$ & $1662.00 \mathrm{abcd}$ \\
\hline SAUSR 09 & $21.33 c$ & $26.00 \mathrm{e}$ & $29.33 \mathrm{c}$ & $87.00 \mathrm{ab}$ & $6.67 a b$ & $8.67 \mathrm{a}$ & $81.67 b c$ & $175.33 \mathrm{ab}$ & $17.15 b$ & $5.73 \mathrm{ab}$ & $4.23 \mathrm{ab}$ & $1506.00 \mathrm{abcd}$ \\
\hline SAUSR 10 & $22.00 \mathrm{bc}$ & $27.67 \mathrm{de}$ & $30.00 \mathrm{bc}$ & $88.67 \mathrm{ab}$ & $5.67 \mathrm{bc}$ & $4.00 \mathrm{bcd}$ & $81.67 b c$ & $121.67 \mathrm{bc}$ & $16.30 \mathrm{~b}$ & $5.43 \mathrm{abc}$ & $3.51 \mathrm{bcd}$ & 1529.00abcd \\
\hline SAUSR 11 & $23.33 \mathrm{bc}$ & $27.67 \mathrm{de}$ & $30.00 \mathrm{bc}$ & $88.33 \mathrm{ab}$ & $5.67 b c$ & $4.33 \mathrm{bcd}$ & $81.33 b c$ & $148.33 b$ & $17.37 \mathrm{~b}$ & $5.43 \mathrm{abc}$ & $3.45 \mathrm{bcd}$ & $1158.00 \mathrm{~cd}$ \\
\hline SAUSR 12 & $24.33 b c$ & $28.67 \mathrm{cde}$ & $30.00 \mathrm{bc}$ & $84.00 \mathrm{ab}$ & $4.33 c$ & $3.67 \mathrm{bcd}$ & $89.67 \mathrm{abc}$ & $124.67 b c$ & $15.43 b$ & $5.53 \mathrm{abc}$ & $3.57 \mathrm{abcd}$ & $1049.67 d$ \\
\hline SAUSR 13 & $24.67 \mathrm{bc}$ & $28.33 \mathrm{cde}$ & $31.67 \mathrm{bc}$ & $87.00 \mathrm{ab}$ & $4.67 \mathrm{c}$ & $4.33 \mathrm{bcd}$ & $80.67 \mathrm{c}$ & $128.67 \mathrm{bc}$ & $17.09 \mathrm{~b}$ & $5.27 \mathrm{abc}$ & $3.49 \mathrm{bcd}$ & $1338.00 \mathrm{bcd}$ \\
\hline SAUSR 14 & $25.33 b c$ & $30.00 \mathrm{bcd}$ & $33.33 b c$ & $86.33 \mathrm{ab}$ & $5.67 \mathrm{bc}$ & $5.33 b c$ & $92.33 \mathrm{ab}$ & $181.67 \mathrm{ab}$ & $16.64 \mathrm{~b}$ & $5.40 \mathrm{abc}$ & $3.87 \mathrm{abc}$ & $2111.33 \mathrm{a}$ \\
\hline BARI 14 & $28.00 \mathrm{ab}$ & $32.33 \mathrm{~b}$ & $36.00 \mathrm{~b}$ & $73.67 \mathrm{bc}$ & $5.67 \mathrm{bc}$ & $3.00 \mathrm{bcd}$ & $81.00 \mathrm{bc}$ & $80.67 \mathrm{c}$ & $21.69 \mathrm{a}$ & $4.03 \mathrm{~d}$ & $3.34 \mathrm{~cd}$ & $1735.67 \mathrm{abcd}$ \\
\hline BARI 15 & $33.00 \mathrm{a}$ & $43.67 \mathrm{a}$ & $48.00 \mathrm{a}$ & $93.00 \mathrm{a}$ & $8.33 \mathrm{a}$ & $2.00 \mathrm{~cd}$ & $90.00 \mathrm{abc}$ & $129.00 \mathrm{bc}$ & $21.68 \mathrm{a}$ & $4.57 \mathrm{~cd}$ & $3.46 \mathrm{bcd}$ & $2012.67 \mathrm{ab}$ \\
\hline TORI-7 & $27.00 \mathrm{bc}$ & $31.33 b c$ & $34.67 \mathrm{~b}$ & $88.67 \mathrm{ab}$ & $5.00 \mathrm{bc}$ & $4.00 \mathrm{bcd}$ & $86.67 \mathrm{abc}$ & $152.67 \mathrm{ab}$ & $15.49 \mathrm{~b}$ & $4.73 \mathrm{bcd}$ & $2.93 \mathrm{~d}$ & $1552.67 \mathrm{abcd}$ \\
\hline Mean & 24.95 & 29.95 & 32.88 & 84.63 & 5.55 & 4.31 & 86.52 & 146.93 & 17.55 & 5.32 & 3.52 & 1583.09 \\
\hline $\mathrm{CV} \%$ & 12.71 & 4.38 & 7.11 & 10.43 & 18.82 & 41.84 & 6.35 & 24.55 & 10.72 & 11.23 & 12.66 & 21.42 \\
\hline$\delta^{2} \mathrm{~g}$ & 5.19 & 17.68 & 20.89 & 35.08 & 0.66 & 1.81 & 14.23 & 868.86 & 2.71 & 0.19 & 0.10 & 47598.16 \\
\hline$\delta^{2} \mathrm{p}$ & 15.25 & 19.39 & 26.36 & 112.99 & 1.75 & 5.06 & 44.39 & 2170.19 & 6.24 & 0.55 & 0.29 & 162612 \\
\hline$\delta^{2} \mathrm{e}$ & 10.05 & 1.72 & 5.47 & 77.92 & 1.09 & 3.25 & 30.16 & 1301.32 & 3.54 & 0.36 & 0.19 & 115013.9 \\
\hline PCV & 15.65 & 14.71 & 15.61 & 12.56 & 23.81 & 52.21 & 7.70 & 31.71 & 14.23 & 13.86 & 15.56 & 25.47 \\
\hline GCV & 9.13 & 14.04 & 13.89 & 6.99 & 14.59 & 31.24 & 4.36 & 20.06 & 9.37 & 8.14 & 9.04 & 13.78 \\
\hline ECV & 12.71 & 4.38 & 7.11 & 10.43 & 18.82 & 41.83 & 6.35 & 24.56 & 10.72 & 11.22 & 12.66 & 21.42 \\
\hline Heritability $h^{2} b(\%)$ & 34.07 & 91.14 & 79.25 & 31.04 & 37.55 & 35.80 & 32.06 & 40.03 & 43.33 & 34.46 & 33.78 & 29.27 \\
\hline Genetic Advance in $1 \%$ & 2.61 & 7.87 & 7.97 & 6.47 & 0.97 & 1.58 & 4.19 & 35.56 & 2.12 & 0.49 & 0.36 & 23.14 \\
\hline GA in $\%$ of mean in $1 \%$ & 10.45 & 26.27 & 24.25 & 7.64 & 17.53 & 36.64 & 4.84 & 24.88 & 12.09 & 9.36 & 10.29 & 14.61 \\
\hline
\end{tabular}

$\mathrm{CV}=\mathrm{Co}$-efficient of variance, $\delta^{2} \mathrm{~g}=$ Genotypic variance, $\delta^{2} \mathrm{p}=$ Phenotypic variance, $\delta^{2} \mathrm{e}=$ Environmental variance, PCV=Phenotypic Co-efficient of Variation,

$\mathrm{GCV}=$ Genotypic Co-efficient of Variation and ECV= Environmental Co-efficient of Variation, GA= Genetic Advance 
Saifullah (2010) reported significant positive correlation for days to 50\% flowering while Malik et al. (2000) found highly significant negative correlation of days to flowering to yield per hectare. Plant height showed significant negative correlation with yield per hectare, number of primary branches per plant, number of secondary branches per plant and number of seeds per siliquae. Positive significant correlation of plant height was observed in days to maturity. Khan et al. (2008) found positive non-significant correlation of plant height with yield per hectare.

Moderate heritability with moderate genetic advance in percentage of mean was observed in number of seeds per siliquae and thousand seed weight. The environmental variance was low in both case indicated that more influence of genetic components to express the character. In accordance with our result, low genetic advance was reported by Jahan (2008) and Saifullah (2010) for the traits in Brassica rapa.

It was evaluated that days to maturity revealed moderate heritability with low genetic advance where the genetic variance was one third of phenotypic variance. The environmental variance was very high. The results concluded that the character was mostly controlled by non-additive genes and more influence of environment in the phenotypic expression of the characters. Similar to our result, Naznin (2013) also found high heritability $(89.14 \%)$ with low genetic advance $(8.69 \%)$ for the character days to maturity in rapeseed.

Moderate heritability with high genetic advance was found in yield per hectare. The environmental variance was much high. It represented predominant additive gene action with more environmental influence. There were both genotypic and environmental influence for phenotypic expression of the trait. In supporting of our results, Rameeh (2014) also found high heritability with high genetic advance for seed yield in B. napus. But Naznin (2013) found high heritability (57.05\%) with low genetic advance (0.99\%) for the trait.

From variability studies it was seen that SAUSR 14 produced more yield than the popular check varieties with non-significant variation with BARI Sharisha 15 . The heritability and genetic advance studies stated that the yield per hectare was governed by both genotypic and environmental components. The advanced line SAUSR 08 showed earlier maturity with moderate yield per hectare than the check varieties and the heritability for days to maturity was moderate. So these two lines might be selected as promising lines for further processing of high yielding and early matured Brassica rapa varieties.

\section{Correlation Co-efficient:}

Yield is controlled by polygene and highly influenced by environment. For this reason, selection based on only yield itself is ineffective. Correlation co-efficient helps the plant breeders to select the yield contributing traits to be given importance by its nature and magnitude. Simultaneous improvement of various characters along with the yield is also possible through correlation co-efficient. In this study phenotypic correlation co-efficient was studied to find out the relative contributions of the yield treating characters for better selection and the results of the eleven characters under the experiment is presented in table 4.

Days to first flowering showed positive non-significant relationship with yield but high positive significant correlation with the days to 50\% and $80 \%$ flowering. Highly significant negative correlation was found with number of secondary branches per plant and siliquae length. 
Table 4. Phenotypic $\left(r_{p}\right)$ correlation among different yield and yield contributing characters of 14 genotypes of Brassica rapa

\begin{tabular}{|c|c|c|c|c|c|c|c|c|c|c|c|}
\hline Characters & DFiF & DEF & $\mathrm{PH}(\mathrm{cm})$ & NPBP & NSBP & $\mathrm{DM}$ & NSP & NSS & $\mathrm{SL}(\mathrm{cm})$ & TSW $(\mathrm{g})$ & $\mathrm{YH}(\mathrm{kg})$ \\
\hline DFF & $0.53 * *$ & $0.48 * *$ & -0.07 & 0.34 & -0.25 ** & 0.04 & $\begin{array}{l}-0.14 \\
\end{array}$ & 0.27 & $-0.34 * *$ & $-0.15 *$ & 0.14 \\
\hline DFiF & & $0.70 * *$ & $0.50 * *$ & $-0.42 *$ & $-0.56^{* *}$ & $0.52 * *$ & -0.33 & $-0.51 * *$ & $-0.26 * *$ & -0.39 & $-0.54 * *$ \\
\hline DEF & & & 0.1 & $0.46 * *$ & $-0.36^{* *}$ & $0.25 * *$ & -0.15 & $0.53 * *$ & $-0.47 * *$ & $-0.20 * *$ & $0.39 * *$ \\
\hline $\mathrm{PH}(\mathrm{cm})$ & & & & $-0.36^{*}$ & $-0.47 *$ & $0.44 *$ & -0.28 & $-0.44 *$ & -0.03 & -0.4 & $-0.46^{*}$ \\
\hline NPBP & & & & & $0.39 *$ & $-0.37 *$ & 0.24 & $0.37 *$ & $-0.17 *$ & 0.28 & $0.39 *$ \\
\hline NSBP & & & & & & $-0.49 *$ & 0.31 & $0.48^{*}$ & $0.23 * *$ & 0.37 & $0.51 * *$ \\
\hline DM & & & & & & & -0.29 & $-0.45^{*}$ & 0.17 & -0.34 & $-0.48 *$ \\
\hline NSP & & & & & & & & 0.29 & $0.28 * *$ & 0.22 & 0.31 \\
\hline NSS & & & & & & & & & -0.12 & 0.34 & $0.47 *$ \\
\hline $\mathrm{SL}(\mathrm{cm})$ & & & & & & & & & & $0.24 * *$ & $-0.14 * *$ \\
\hline TSW & & & & & & & & & & & -0.22 \\
\hline
\end{tabular}

$*=$ significant $(\mathrm{P}<0.05)$ and $* *=$ highly significant $(\mathrm{P}<0.01)$ 
Days to 50\% flowering showed highly significant negative correlation with the yield per hectare, number of primary branches per plant, number of secondary branches per plant, number of seeds per siliquae and siliquae length. Highly significant positive correlation was found with days to $80 \%$ flowering, plant height and days to maturity. Highly significant positive correlation was observed with yield per hectare, number of primary branches per plant, days to maturity and seeds per siliquae where highly significant negative correlation was found in number of secondary branches per plant, siliquae length and thousand seed weight. Number of primary branches per plant showed positive significant correlation with the yield per hectare, number of secondary branches per plant and number of seeds per siliquae. Negative significant correlation was found for the trait in days to maturity and siliquae length. Alam (2010) supported our result as he also found significant positive correlation of number of primary branches per plant with yield per hectare.

Highly significant positive correlation of number of secondary branches per plant was found for yield per hectare and siliquae length. Significant negative and significant positive correlation was observed in days to maturity and number of seeds per siliquae, respectively. Akter (2010) found negative correlation between number of secondary branches per plant and seed yield. Days to maturity showed negative significant correlation with the yield per hectare and number of seeds per siliquae. Mekonnen et al. (2014) found positive but non-significant correlation between the characters and yield per hectare.

Positive but non-significant correlation was observed between the number of siliqua per plant and yield per hectare. Highly significant positive correlation was found only for siliquae length. Hosen (2008) reported negative correlation of the trait with length of siliquae, yield and thousand seed weight. Number of seeds per siliquae showed significant positive correlation with yield per hectare. Gangapur et al. (2009) found highly significant phenotypic correlation of number of seeds per siliquae and yield per meter square for both protected and unprotected condition. Siliquae length showed highly significant correlation with the yield per hectare and thousand seed weight. Maurya et al. (2012) found positive significant phenotypic correlation with the seed yield. Thousand seed weight showed negative non-significant correlation with the yield per hectare. Similar results was found by Kardam and Singh (2005).

Positive significant correlation with yield per hectare was observed in days to $80 \%$ flowering, number of primary branches per plant, number of secondary branches per plant and number of seeds per siliquae. The results revealed that direct selection of these character would be effective to increase yield of the advanced lines.

The advanced lines showed variations in their performance among all the genotypes found from the variability studies. Days to fifty percent flowering and days to eighty percent flowering showed high heritability where number of siliquae per plant and yield per hectare that indicated that the selection of these character would be effective for further improvement. For betterment of yield, selection of the characters that showed significant positive association with yield per hectare would be useful.

\section{REFERENCES:}

Akter, M. M. 2010. Variability study in $\mathrm{F}_{4}$ populations obtained through intervarietal crosses of Brassica rapa. MS Thesis, Dept. of Genetics and Plant Breeding, SAU, Dhaka.

Allard, R. W. 1960. Principles of plant breeding. Jhon Willey and Sons. Inc.New York. pp.36. 
Alam, M. F. 2010. Variability studies in $\mathrm{F}_{4}$ progenies of Brassica rapa, obtained through intervarital crosses. M.S. Thesis. Dept. of Genetics and Plant Breeding, SAU, Dhaka.

Ali, Y., Farhatullah, H. Rahman, A. Nasim, S. M. Azam and A, Khan. 2013. Heritability and correlation analysis for morphological and biochemical traits in Brassica carinata. Sarhad J. Agric. 29(3): 359369.

BBS. 2011. Year Book of Agricultural Statistics of Bangladesh. Bangladesh Bureau of Statistics, Ministry of Planning. Govt. People's Republic of Bangladesh. p. 38332.

Downey, R. K, G. Robbelen. 1989. Brassica species: Oil crops of the world, their breeding and utilization. McGraw Hill Publishing Co., New York. pp. 339-374.

FAO. (2005). Production Year Book. Food and Agricultural Organization, Rome, Italy. p.118.

FAO. 2013. Food and Agriculture Organization of the United Nations, FAOSTAT. FAO Statistics Division.

Gaines, C. S., P. L. Finney and G. Raubenthaler. 1996. Milling and baking qualities of some wheat developed for Eastern or North-Western Regions of the United States and grown at both locations. Cereal Chem. 73: 521-525.

Gangapur, D. R., B. G. Prakash, P. M., Salimath, R. L. Ravikumar, and M. S. L. Rao. 2009. Correlation and path analysis in Indian mustard (Brassica juncea L. Czren and Coss). Karmataka J. Agric. Sci. 22(5):971-977.

Gomez, K. A. and A. A. Gomez. 1984. Statistical procedure for agricultural research $\left(2^{\text {nd }}\right.$ ed.). Wiley, New York. pp. 28-192.

Hosen, M. 2008. Variability, correlation and path analysis in $F_{3}$ materials of Brassica rapa. MS Thesis, Dept. of Genetics and Plant Breeding, SAU, Dhaka.

Iqbal, S., Farhatullah, S. Shah, M. Kanwal, L. Fayyaz and M. Afzal. 2014. Genetic variability and heritability studies in indigenous Brassica rapa accessions. Pak. J. Bot. 46(2): 609-612.

Johnson, H. W., H. F. Robinson and R. E. Comstock. 1955. Estimation of genetic and environmental variability in Soybean. Agron. J. 47:314-318.

Junaid, M., M. Raziuddin, M. Kanwal, M. Umair, S. Ahmed, N. Ahmed, A. A. Alizai and N. Bano. 2014. Heritability ${ }_{(\mathrm{BS})}$ and selection response estimates for yield and yield related traits in Brassica napus. J. Mater. Environ. Sci. 5 (4):1107-1110.

Jahan, N. 2008. Inter-genotypic variability and genetic diversity analysis in $\mathrm{F}_{4}$ lines of Brassica rapa. MS thesis, Dept. of Genetics and Plant Breeding, SAU, Dhaka.

Kahrizi, D. and T. Alaahvarand. 2012. Estimation and interrelationship of genetic variability parameters of some morpho-phenologican traits in Spring Rapeseed (Brassica napus L.). Asian Biol. Sci. 5(7):358-364.

Kardam, D. K. and V. V. Singh. 2005. Correlation and path analysis in Indian mustard (Brassica juncea (L.) Czern and Coss) grown under rainfed condition. J. Spices and Aromatic Crops. 14(1): 56-60.

Khan, S., Farhatullah and I. H. Khalil. 2008. Phenotypic correlation analysis of elite $F_{3: 4}$ Brassica populations for quantitative and qualitative traits. ARPN J. Agric. and Biol. Sci. 3:38-42.

Khan, F. U., R. Uddin, I. A. Khalil, I. H. Khalil and I. Ullah. 2013a. Heritability and genetic potential of Brassica napus genotypes for yield and yield components. Am-Euras J. Agric. And Environ. Sci. 13(6):802-806.

Khan, M. H., S. R. Bhuiyan, M. H. Rashid, S. Ghosh and S. K. Paul. 2013b. Variability and heritability analysis in short duration and high yielding Brassica rapa $\mathrm{L}$. Bangladesh J. Agril. Res. 38(4): 647-657. 
Malik, M. A., A. S. Khan, Shafiuallah and M. K. Ayub. 2000. Study of correlation among morphological parameters in different varieties/ accessions of Brassica species. Paki. J. Bio. Sci. 3(7): 1180-1182.

Maurya, N., A. K. Singh, and S. K. Singh. 2012. Inter-relationship analysis of yield and yield components in Indian mustard, Brassica juncea L. Indian J. Plant Sci. $1(23): 90-92$.

Mekonnen, T. W., A. Wakjira, and T. Genet. 2014. Correlation and path coefficient analysis among yield component traits of Ethiopian mustard (Brassica carinata a. Brun) at Adet, Northwestern, Ethiopia J. Plant Sci. 2(2):89-96.

Nagaharu, U. 1935. Genome analysis in Brassica with special reference to the experimental formation of Brassica napus and peculiar mode of fertilization. Japan. J. Bot. 7:389-452.

Naznin, S. 2013. Variability, character association and divergence in rapeseed advanced lines. MS Thesis, Dept. of Genetics and Plant Breeding, SAU, Dhaka.

Novoselovic, D., M. Baric, G. Drezner, J. Gunjaca and A. Lalic. 2004. Quantitative inheritance of some wheat plant traits. Genet. Mol. Biol. 27(1): 92-98.

Rahman, L. M. and Z. A. M. Chowdhury. 2010. Agricultural research priority: Vision2030 and beyond.pp.3-45.

Rameeh, V. 2014. Multivariate regression analysis of yield associated traits in rapeseed (Brassica napus L.) genotypes. Adv. in Agril. 626434.

Roy, S. K., S. Haque, V. A. Kale, D. S. Asabe and S. Dash. 2011. Variability and character association studies in rapeseed-mustard (Brassica sp.). J. Crop and Weed. 7(2).108-112.

Saifullah, M. 2010. Variability study among the $\mathrm{F}_{2}$ segregants of the intervarietal crosses of Brassica rapa. MS Thesis, Dept. of Genetics and Plant Breeding, SAU, Dhaka.

Singh, P. K. and B. D. Chaudhary. 1985. Biometrical methods in quantitative genetic analysis. Kalyani Publishers, New Delhi, India. pp. 318.

United States Department of Agriculture (USDA). 2005. Mustard production statisticshistorical data. National agricultural statistics service of USDA. p. 22-26.

United States Department of Agriculture (USDA). 2014. Mustard production statisticshistorical data. National agricultural statistics service of USDA.

Yarnell, S. H., B. Raiand and B. Singh. 1956. Component analysis of harvest index in Brassica Oilseeds. Indian Breeding. J. Agric. Res. 20(3): 129-134. 